\title{
Fulfilling the Call to Holiness in the Views of Cardinal Stefan Wyszyński. An Outline of the Problem in the Light of the Ascetic Teachings of the Servant of God
}

\author{
JACEK HADRYŚ \\ Adam Mickiewicz University in Poznań \\ jacekh@amu.edu.pl, ORCID: 0000-0001-6109-175X
}

\begin{abstract}
The article outlines the issue of fulfilling the call to holiness based on the hitherto little-known ascetic teachings of Stefan Cardinal Wyszyński. All the research work was carried out by analyzing Wyszyński's statements about the universal call to holiness and its four dimensions: theological, moral, ecclesial and psychological. The results of the analysis of the source texts were assessed in the light of the exhortation Gaudete et exsultate by Pope Francis. It was found that Wyszyński's teachings on the realization of the call to holiness lost nothing of its topicality and is fully rooted in the tradition of the Church.
\end{abstract}

Keywords: holiness, spirituality, vocation, Wyszyński, Francis

The Second Vatican Council underlined the call to holiness ${ }^{1}$ as the full participation in God's life. The fullness of life in God is sometimes understood differently (e.g., as Christian perfection or union with God); however, it is mostly referred to as sanctity or holiness. ${ }^{2}$ On the Solemnity of Saint Joseph in 2018, Pope Francis issued

1 Manuela Plans Belda (Guiados por el Espíritu de Dios, 41-42) defines the biblical understanding of holiness as follows: "En el Antiguo Testamento, el vocablo «santo» (qadosh) proviene de la raíz hebrea qds, que expresa la idea de "cortar», «separar». Que Dios es «Santo» significa su absoluta trascendencia en relación con las creaturas, su infinita majestad y grandeza: «Yo soy Dios, y no un hombre; soy el Santo en medio de ti» (Os 11,9; cfr. Sal 98). Solamente Dios es santo: «No hay Santo como el Señor» (1 S 2: 2). La santidad de Dios es suprema: «!Santo, Santo, Santo es el Señor de los ejércitos! ¡Llena está toda la tierra de su gloria!». En el lenguaje bíblico, «El Santo» no expresa una característica más de Dios, sino su propia esencia, el hecho de que Dios es Dios y no una creatura. Dios manifiesta y comunica su santidad, santificando a las creaturas [...] En el Nuevo Testamento, Jesús es llamado «Santo», por el Arcángel san Gabriel: «Respondió el ángel y le dijo: El Espíritu Santo descenderá sobre ti y el poder del Altísimo te cubrirá con su sombra; por eso, el que nacerá Santo será llamado Hijo de Dios» (Lc 1,35). En este texto se revela que Jesucristo tiene la misma santidad que Dios."

2 Catechism of the Catholic Church, No. 825, states: "«The Church on earth is endowed already with a sanctity that is real though imperfect» (LG 48 \# 3). In her members perfect holiness is something yet to be acquired: «Strengthened by so many and such great means of salvation, all the faithful, whatever their 
an apostolic exhortation Gaudete exsultate 3 on the call to holiness in the modern world. As the Holy Father pointed out, his aim was to "repropose the call to holiness in a practical way for our own time, with all its risks, challenges and opportunities" (GE 2). Pope Francis encouraged people to strive toward holiness, pointing out that it is possible in the modern world. He also stated the dangers which threaten it and its various determinants. ${ }^{4}$ The scheduling of Cardinal Wyszyński's beatification on June 7, 2020 (postponed for the time after the COVID-19 pandemic) increased interest in his life, teaching and 33 years of service as a primate. The author of the article, inspired by Pope Francis' exhortation of Gaudete et exsultate, decided to present Cardinal's teachings on the striving toward holiness on the basis of his utterances. The article presents Wyszyński's teachings from the period of 1942-1981, which on various occasions was directly addressed to consecrated religious people, in particular to the members of the Secular Institute of Women Helpers of the Virgin Mary of Jasna Góra (Clarus Mons), Mother of the Church. ${ }^{5}$ Among the source texts subjected to analysis are some of Wyszyński's utterances (numbering more than 3000), namely the ones which discussed the topic of striving toward holiness. ${ }^{6}$ These utterances have a spiritual character and appear to be little known, as only some of them have been published. The author of the article is aware of the fact that a dozen or so publications have been published on the subject of the call to holiness in the view of Wyszyński, and that they are based primarily on the well-known homilies and sermons of the primate. However, he considered it advisable to present how these matters were presented to the secular consecrated by the cardinal. ${ }^{7}$ The results of

condition or state - though each in his own way - are called by the Lord to that perfection of sanctity by which the Father himself is perfect» (LG 11 \# 3)." See Hadryś, Dynamika chrześcijańskiego życia duchowego, 52-60; Gogola, Teologia komunii z Bogiem, 104; Hadryś, "Różne ujęcia pełni życia chrześcijańskiego," 243-247.

3 Francis, Gaudete et exsultate. On the Call to Holiness in Today's World.

4 See: Roszak - Orłowski, Świętość - wysiłek czy laska?; Dąbrowski, "Moralno-pastoralne aspekty świętości," 19-27.

5 The article addresses holiness in the moral sense, which a Christian person is supposed to realise with their entire life, and not about ontic holiness, which is received in baptism: "La santidad moral no es más que el desarrollo de la santidad ontológica en el obrar del cristiano, como enseña san Pedro [...]. En este sentido, la santidad es una tarea que Dios confía al hombre. [...] el cristiano no puede seguir llevando una existencia pagana o mundana, sino que debe vivir según Cristo" (Plans Belda, Guiados por el Espíritu de Dios, 44).

6 Since 2005, the Institute of Women Helpers of the Virgin Mary of Jasna Góra, Mother of the Church is called the Institute of Primate Wyszyński. The texts by Wyszyński, bearing appropriate numbering and used in this article, are typescripts and come from the archives of the above mentioned Institute.

7 See: Fortuniak, "Chrześcijańska koncepcja pracy," 85-103; Tomziński, "Prymas spod znaku Jasnej Pani," 77-91; Miziołek, "Życie i duchowość Stefana Wyszyńskiego," 9-34; Bortkiewicz, "Zbawczy charakter pracy człowieka," 291-310; Bortkiewicz, Etos pracy; Bartoszewski, "Ku beatyfikacji," 506-510; Ewartowska, "Bóg Ojciec a przybrani synowie," 41-57; Głowacki, "Wierność Bogu znakiem chrześcijańskiego życia," 29-38; Król, "Rola pracy," 39-52; Misiurek, "Chrześcijańskie życie duchowe," 398-420; Maćko, "Znaczenie modlitwy," 83-91; Werbiński, "Duchowość pracy ludzkiej," 105-131. 
research works are presented in this article with reference to the universal call to holiness and its four dimensions: theological, moral, ecclesial and anthropological. ${ }^{8}$ The relevant excerpts from Pope Francis' exhortation Gaudete et exsultate were also invoked for each of these dimensions. The author of the article is aware that the existential and ecclesial context of Cardinal Wyszyński and Pope Francis' statements is different; they set different goals for themselves when reflecting upon the call to holiness. However, the fact that they concern the same issue, and their statements are similar, not necessarily in terms of science but both have a pastoral character, made it advisable for the author to compare. ${ }^{9}$ The author has been committed to the analysis and development of Wyszyński's teachings for nearly 20 years, however, due to the formula of the article, the subject matter of the article has been presented only in outline, and the full theological and pastoral reflection on this issue is the objective of the continued works aimed at publishing a special monograph after the beatification of the Primate of the Millennium. Addressing the issue in a limited form of an article necessitated the omission of, among others, the Marian aspect of striving for full life in God as well as the manifestations and features of holiness.

\section{The Call to Holiness}

Every Christian is called to holiness through the sacrament of baptism. Love is a measure of holiness, and the baptized person should grow in it through the word of God, the Eucharist, prayer, sacrifice for others, helping them and confessing Christ, witnessing for Him with life. ${ }^{10}$ Wyszyński was aware of the universality of the call to holiness, which he spoke about in the context of the teachings of the Second Vatican Council: "The Church at the Council [...] reminded in the Dogmatic Constitution on the Church that we are all called to holiness"11 and when referring to the sacraments of baptism and confirmation: "All are in a sense ordained by baptism, by confirmation, and by other sacraments. Therefore, the holy apostolic writers rightly called all the faithful [...] saintly people."12 When justifying the need to care for personal holiness on the part of the baptized person, Wyszyński made a special reference to the call to the apostolate. He believed that in order to successfully help others in at-

8 Jerzy Gogola (Teologia komunii z Bogiem, 106) outlined the ideal of Christian perfection (holiness) by pointing out four dimensions of development that mutually interweave one another striving to reach their relative fullness: theological, moral, ecclesial (communal) and psychological. In this article, the fulfilment of the call to holiness according to Cardinal Wyszyński is presented with reference to this scheme.

9 See also Hadryś, "Jedna świętość czy dwie różne?," 111-126.

10 Cf. Wyszyński, "Rozdział V i VI - O Powszechnym powołaniu do świętości,” No. 374, 2-9.

11 Wyszyński, "Środki Bożego awansu," 28.

12 Wyszyński, "Apostolstwo świeckich w Kościele," No. 758, 2. 
taining salvation, it is necessary to undertake efforts for one's self-improvement and lead a deep, personal, spiritual life. According to the primate, every believer, supported by God's grace, is not only able to overcome even their most difficult, capricious temper, but is also obliged to undertake this task. Wyszyński emphasized that assisting our neighbours in gaining salvation must be combined with efforts aimed at one's advancement and self-improvement. According to the cardinal, it is the duty of the baptized person to prepare for the fulfilment of the baptismal call to the apostolate by self-control and work on internal improvement. This work toward self-improvement should be constant, that is, undertaken throughout life ${ }^{13}$ : "The better a person performs apostolic work, the better they are at self-improvement. The more fruitful the apostolic work is, the more reliable the internal efforts are. If a person undertakes considerable effort in the pursuit of self-improvement, they become able to distinguish the areas of apostolic work themselves and respond to them." 14

Wyszyński's reference to holiness in the justification of the call to holiness in the teaching of the Second Vatican Council and the spirituality of the sacraments of baptism and confirmation is in harmony with the words of Pope Francis in his exhortation Gaudete et exsultate: "We are all called to be holy by living our lives with love and by bearing witness in everything we do, wherever we find ourselves" (GE 14). Francis reminded thereby that this vocation concerns every baptized person, that is, among others, husbands, wives, parents, grandmothers and grandparents, educators, employees and the ruling class. No one is excluded from the call to holiness since everyone has received it with the grace of holy baptism (cf. GE 14-15). According to the Holy Father, by giving a call to holiness, God guarantees the power of the Holy Spirit to make one capable of taking up and fulfilling this call (cf. GE 15).

\section{The Theological Dimension of Holiness ${ }^{15}$}

The source of human holiness is God, who communicates Himself to people through Christ. ${ }^{16}$ The closer a person is to God, the greater their share will be in His holiness. Theologically speaking, it can be said that already upon baptism, a man or woman becomes a participant in God's holiness, however, looking at the problem

13 Cf. Wyszyński, “Charakter Instytutu Pomocnic Matki Kościoła," No. 2572, 8; Wyszyński, "Prośba o pomoc w pracy nad sobą." No. 2573, 1-7.

14 Wyszyński, “Charakter naszego Instytutu," No. 1948, 10.

15 Jerzy Gogola (Teologia komunii z Bogiem, 106) states, "In Christian perfection the most important thing is the personal relationship with God. Since this relationship is created by faith, hope and love, i.e. the theological virtues, hence this dimension is named theological."

16 Jean-Pierre de Caussade (Abandonment to Divine Providence, 62) states: "The divine action alone can sanctify us, for that alone can make us imitate the divine Example of our perfection." 
from a practical and moral perspective, they are obliged to cooperate with God's grace and personally strive to reach full participation in God's holiness, that is, to reach the fullness of Christian life. ${ }^{17}$ The realization of the call to holiness takes place through the development of the theological virtues of faith, hope and love, and the achievement of their fulness culminates in the union with God. ${ }^{18}$ In the light of the above, noteworthy is Wyszyński's statement whereby although the very presence of God in a baptized person makes them saintly, it is particularly important to "look at Christ, at His face, at His style of conduct, speech, response, conversation, discussion, [...] this means being implanted, being rooted in Christ, this means getting closer to the pattern of His image that God wanted to leave to us." ${ }^{19}$ A deeply religious Christian "wants to be with Him everywhere and share God's most perilous strokes of fate. [...] The entire inner life, the entire striving for the union with God is to be based on the person of Christ"20: the Primate was of the opinion that holiness is not determined by a large number of prayers, because there are people who do not have the conditions to devote a lot of time to prayer, and also, that holiness does not consist in fidelity, for there are Christians who faithfully obey all rules and regulations, and are not saintly." ${ }^{21}$ According to the cardinal, "holiness is a tiny seed that grows in the soul [...]. Holiness is my inner relationship to my God who lives in me [...]. It is the awareness that $\mathrm{He}$ is in me. He acts and I just submit to Him. [...] Holiness is my God in me."22 For this reason, Wyszyński believed that you do not need to say much to God, but it is enough to be submissive to Him in everything: "This is some inner calming down, and inner opening to God. When this is our attitude to Him, we forget about the whole world. Then the mouth goes silent, the heart opens. [...] Each of us creates our own holiness. [...] This is the essence - total submission to God and union with Him through love, full hope. It is the essence of holiness and only this can be imitated."23 A personal connection with Christ is essential in fulfilling the call to holiness, and it comes to fruition as submission to the Saviour in all things. ${ }^{24}$

17 Second Vatican Council, Lumen gentium, 40: "The followers of Christ are called by God, not because of their works, but according to His own purpose and grace. They are justified in the Lord Jesus, because in the baptism of faith they truly become sons of God and sharers in the divine nature. In this way they are really made holy. Then too, by God's gift, they must hold on to and complete in their lives this holiness they have received."

18 Gogola, Teologia komunii $z$ Bogiem,106.

19 Wyszyński, “Światła Boże na ludzkich drogach," No. 936, 12.

20 Wyszyński, “Tajemnica powołania...,” No. 813, 2.

21 Wyszyński, "Homilia na uroczystość Wszystkich Świętych," No. 1958, 4.

22 Wyszyński, "Homilia na uroczystość Wszystkich Świętych," No. 1958, 5.

23 Wyszyński, "Homilia na uroczystość Wszystkich Świętych," No. 1958, 4-5.

24 Stanisław Urbański ("Chrystoformizacja," 242) describes the Christian call to holiness in the following way, "Following means trying to 'become' like Jesus. Therefore, Christian holiness relies on being like Jesus. [...] Such following shows that our decisions somehow depend on God, which suggests 'the unity of the spirit.' And in this mystical state of mind, a man or woman wishes the same that God does. Having 
As already mentioned, the essence of Christian holiness lies in a personal, profound connection of a baptized person with Christ, which means full development of the virtues of faith, hope, and love, i.e., the so-called theological dimension of holiness. The teaching of Franciszek is in harmony with the teaching of Wyszyński on that matter: "the measure of our holiness stems from the stature that Christ achieves in us, to the extent that, by the power of the Holy Spirit, we model our whole life on his" (GE 21). According to the Pope, holiness consists in recreating various aspects of Jesus Christ's earthly life on earth in one's own personal life (cf. GE 20). The contemplation of the earthly life of the Son of God, various manifestations of His love and being for others, can greatly assist in this reflection of Christ's life, because everything that Christ experienced and lived through happened with a view to making His believers able to experience it in Him, and Him in them (cf. EG 20). There is a striking similarity between Francis' thoughts and the earlier quotations of Wyszyński's statements regarding the admiration of Christ's face.

\section{Moral Dimension of Holiness}

A deep relationship with Christ forms the theological dimension of holiness, which leads to the moral dimension, i.e., doing God's will as Christ did, and who said: "My food is to do the will of Him who sent Me" (John 4:34). This means following in the footsteps of Christ and becoming like Him ${ }^{25}$ which will be expressed in particular love of your neighbour, including serving them even in minor matters. Wyszyński clearly pointed to the bond between the moral dimension of holiness and its theological dimension, stressing the need for personal ${ }^{26}$ connection with Christ and perceiving Him in relations with neighbours, "I would be glad if you saw Christ clear enough in your everyday relations, like in cohabitation at home, on the street, on the tram - anywhere; so that you never miss Christ in anyone; so that you never insult or diminish Him in anyone or even hurt Him in anyone. ${ }^{27}$ The Primate spoke about love to neighbours many times, pointing out that it comes from God's commandment of love and obligates us to help fellows on the way to salvation, i.e., to apostolate, and at the same time influences the effectiveness of such assistance. The argumentation of the need of love to fellows in fulfilling the call to the apostolate is strongly

reached this state of mind, a Christian person performs the will of God to some extent identifying themselves with His will."

25 Thomas à Kempis, The Imitation of Christ, I, 1, 1: "Anyone who follows me shall not walk in darkness', says the Lord. These are the words of Christ, and by them we are reminded that we must imitate his life and his ways if we are to be truly enlightened and set free from the darkness of our own heart."

27 Wyszyński, “Kromka chleba," No. 155, 9-10. 
emphasized in Wyszyński's teaching, which is addressed to the members of the institute. The Primate emphasized the need to be sensitive to others, pay attention to the lost and embrace every human being with love. He pointed to the importance of small, everyday matters and gestures of love. "It's not about serving great things. It is all about serving through small matters and favours, being helpful, generous, kind, able to deal with people, being cautious so as not to offend anyone in any way." ${ }^{28} \mathrm{He}$ emphasized, pointing to God's love for people, that it is possible to love every fellow, "Could I find any unsavoury person who I would not be able to love anymore, as I will always answer myself: How could I? God loves them, still loves them, nonetheless. And when we do not want to look around, let us look at ourselves - and yet God loves me. [...] we actually lose the motivation that could fuel our aversion to anyone. And then it turns out that God's commandment of love is the greatest blessing of love of fellows." 29

Primate Wyszyński was too aware of the difficulties and fears related to the love towards people who have gone terribly astray or those existing on the peripheries of the society, in this context, for example, pointing to the saints who sacrificed themselves for people who needed their help the most, "Fear to give offense shows how complicated the Christian apostolate is. [...] Saintly people who have entered such company are still a source of scandal. And yet whenever they attended to bereaved people, a sort of a social upheaval took place." ${ }^{30}$

The Social Crusade of Love, initiated by Wyszyński in 1967, becomes part of practising love of fellows, i.e., of the moral dimension of holiness. It is expressed in ten concise headwords, the so-called "ABC of the Social Crusade of Love" and denotes day-to-day self-development carried out under the patronage of Blessed Virgin Mary as a model of Christian virtues:

1. Respect every human being, as Jesus Christ lives in them. Be sensitive to other people, your brothers and sisters. 2. Think well of everyone - do not think badly of anyone. Try to find something good even in the worst things. 3. Always speak kindly of others - do not speak badly of your neighbours. Redress the harm done with words. Do not create discord between people. 4. Speak to each person in the language of love. Do not raise your voice. Do not swear. Do not hurt anyone's feelings. Do not bring anyone to tears. Calm people down and show goodness. 5. Forgive everything, everyone. Do not hold a grudge. Always be the first to reach out your hand for reconciliation. 6. Always act to the benefit of your neighbours. Do unto others as you would wish them to do unto you. Do not think of what others owe to you, but what you owe to others. 7. Show compassion actively. Carry consolation, advice, assistance, with your heart, readily. 8 . Work honestly, because the fruit of

\footnotetext{
28 Wyszyński, "Homilia o świętym Janie Vianney," No. 466, 4-5.

29 Wyszyński, “Bóg jest Miłością”" No. 281, 12.

30 Wyszyński, "Powołanie do apostolstwa," No. 2737, 4.
} 
your work is used by others, just as you benefit from the work of others. 9. Get involved in carrying social assistance to your neighbours. Open up to the poor and the sick. Share what you own. Try to see those in need around you. 10. Pray for everyone, even for your enemies. $^{31}$

In the light of the above mentioned, the moral dimension of Christian holiness is therefore, closely connected with the theological dimension in Wyszyński's teaching. It is quite significant, that even Pope Francis when writing about the call to holiness clearly showed its connection to the fulfilment of the mission received from God: "It is not healthy to love silence while fleeing interaction with others, to want peace and quiet while avoiding activity, to seek prayer while disdaining service. Everything can be accepted and integrated into our life in this world and become a part of our path to holiness. We are called to be contemplatives even in the midst of action, and to grow in holiness by responsibly and generously carrying out our proper mission" (GE 26). This mission is the call to apostolate. Each baptized person is called to identify with Christ and His desires, and thus they are obligated to build a Kingdom of love, justice, and peace together with Him (cf. GE 25). "Holiness is also parrhesia: it is boldness, an impulse to evangelize and to leave a mark in this world" (GE 129). It is not difficult to notice that Pope Francis connects the call to holiness with the call to the apostolate, as it was present in Wyszyński's teachings. The Primate of the Millennium, as already mentioned, additionally justified the need for personal pursuit of holiness with the calling to apostleship. Francis, in his turn, seems to have shifted the emphasis more towards combining these two callings. Nevertheless, it can be claimed that Wyszyński's combination of these two callings and the theological and moral dimensions of holiness resulting therefrom, has remained valid.

Sensitivity to the needs of fellows, in particular socially marginalized people, which is so much emphasized by Wyszyński, is a constant moral requirement. As Francis recalled after Benedict XVI, "holiness is nothing other than charity lived to the full" (GE 21). Moreover, Francis emphasized that in beatification and canonization processes, the signs of heroism in practicing virtues are taken into account, as well as "cases where a life is constantly offered for others, even until death" (GE 5). As a path to holiness pleasing God, he indicated the rule of conduct on the basis of which every worshipper of Christ will be judged: "I was hungry and you gave me food, I was thirsty and you gave me drink, I was a stranger and you welcomed me, I was naked and you clothed me, I was sick and you took care of me, I was in prison and you visited me (Matt 25:35-36)" (GE 95). He pointed out that God leads people where humanity is particularly wounded, and people are constantly looking for an answer to the question of the purpose of life: "God is not afraid [...] he himself became a fringe (cf. Phil 2:6-8; John 1:14). So, if we dare to go to the fringes, we will

31 Wyszyński, “ABC Społecznej Krucjaty Miłości." 
find him there; indeed, he is already there" (GE 135). Pope Francis and Wyszyński’s understanding of the moral dimension of holiness seems to be convergent not only in the general sense accepted in the universal Church, but also in the aspects of sensitive love towards the neighbour living on the periphery of society.

\section{Ecclesial Dimension of Holiness}

In his ascetic teachings, Primate Wyszyński emphasized the truth that a man or woman is by nature a social being, ${ }^{32}$ therefore "they cannot reach absolute perfection alone. If they isolate themselves, it means that they are not mature yet, as absolute perfection means engaging in people and coexisting with them. [...] And an isolated person will not gain what people are obliged to give them from the Father's love, from the saving kingship of Christ and the leading power of the Church." ${ }^{33}$ He was aware of the fact that it is a great torment for a human being to avoid others because this leads to impoverishment and egocentricity: "There is no worse torment, no worse anguish than treating yourself with your own selfishness. [...] People must share Themselves with others as the Father gave Himself to the Son and must draw from others as the Son draws from the Father at the same time reaching out to the Father. Only then does it give this great love. [...] Only then does the human being develop." ${ }^{44}$ Therefore, it is not surprising that the cardinal stresses the communal dimension of the pursuit of holiness. This aspiration is fulfilled in the Church where a man or woman becomes formally included upon receiving the sacrament of baptism. The baptized person is part of the supernatural organism of the Church, which, like any organism, consists of different members performing different functions. Individual members interact with each other and help each other. ${ }^{35}$ Wyszyński reminded that even though there occur such powerful individual actions in the Church that give rise to saints in various areas of life, there are still many people who need help: "Salvation in the Christian order takes place in the Church, and the Church is «Ecclesia», which means a collection, gathering, community, and not only in terms of the liturgical activity and the Sacrifice of the Altar, but also in the universal, Catholic terms, i.e. Ecclesia universalis." ${ }^{36}$ This happens so because it is much easier to strive for God together than individually. Quite a few people may be in spiritual slumber, but since

\footnotetext{
32 Cf. Wyszyński, "Komentarz Konstytucji pastoralnej," No. 419, 6-9; Wyszyński, "Na drodze do odnowy," No. 2661, 2-3.

33 Wyszyński, "Na drodze do odnowy," No. 2661, 14-15.

34 Wyszyński, "Uroczystość Świętej Rodziny," No. 387, 3-4.

35 Cf. Wyszyński, "Społeczny charakter osoby ludzkiej," No. 1941, 2; cf. Wyszyński, "Komentarz Konstytucji pastoralnej," No. 419, 18-20.

36 Wyszyński, "Społeczny charakter osoby ludzkiej," No. 1941, 3.
} 
they are in a community these people submit to its supernatural mechanism and, as a result, they are prompted to act and behave in such a way that they would never follow on their own. The purely sociological contact with others in the Church is magnified through supernatural ties. Thanks to them, a person participates in those spiritual energies which pulsate throughout the body of the Church. From time to time a person who has fallen into spiritual lethargy awakens and becomes aware of their place in the supernatural organism of the Church, and thus, of their duties and tasks in this organism. All this, according to Wyszyński, indicates the necessity of social, collective striving for God. ${ }^{37}$

The baptized participate in the Church not so much through legal bonds, but more through spiritual, or supernatural, bonds. Every action of the baptized person, including their personal striving for holiness, has an ecclesial dimension; it is the action of the Church. According to Wyszyński, "all baptized people are called to participate in the Church not so much through legal and juridical bonds, but rather through spiritual, supernatural ones, through internal participation in the life of the Church." ${ }^{38}$ The actions of the baptized person are always, also unconsciously, the actions of the Church, although "the more conscious they are, the more effective they get, but even if it were unconscious, it would still remain an action of the Church. [...] The whole Church is constantly working on me." ${ }^{39}$ The Lord God, with His sanctifying action, comes to the baptized person through the Church. According to Wyszyński, for this reason each baptized person is obliged to maintain communication with the Church and meet God in a manner specified by Him, that is in the spirit of truths and mysteries taken into consideration in a given period of the church year. This meeting with God takes place in a special way thanks to the connection with the Church and is an expression of a certain obedience, submission to the Church, which Wyszyński expressed bluntly: "I just have an appetite for Easter, and now it is Christmas." ${ }^{40}$ This obedience to the Church is of educational because it is guided by the Holy Spirit and rewarded with its graces. A relationship with God should not be developed according to one's own idea, but as God wishes and communicates it through the Church: "You have to trust the Church and renounce the prayer to which I am used, for the prayer of the Church. [...] This partly overcomes our individualism and is a repetition [...] of theological knowledge."41 Emphasizing the experience of his relationship with God in the Church, the Primate also encouraged us to "pray as the Holy Father prays at the moment: he knows what is most needed." ${ }^{22}$ In Wyszyńs-

\footnotetext{
37 Cf. Wyszyński, "Społeczny charakter osoby ludzkiej," No. 1941, 2.

38 Wyszyński, "Nadprzyrodzona zależność od Kościoła," No. 328, 3.

39 Wyszyński, "Nadprzyrodzona zależność od Kościoła," No. 328, 5-6.

40 Wyszyński, "Modlitwa Zespołu," No. 18, 6.

41 Wyszyński, "Modlitwa Zespołu," No. 18, 6.

42 Wyszyński, "Modlitwa Zespołu," No. 18, 8. Cf. Wyszyński, "Podczas Mszy świętej," 1; Wyszyński, "Codzienność Świętej Rodziny," No. 588, 2-3.
} 
ki's opinion, the development of theological virtues through prayerful contact with God should be carried out in accordance with the guidelines of the Church inscribed in a given period of the liturgical year.

In his exhortation Pope Francis drew attention to the fact that a baptized person realizes personal relationship with Christ and the attitude of following the Saviour at least partially in the community of the Church. He emphasized that without the Church, true holiness is not possible, because the Holy Spirit leads a baptized person to holiness together with other members of the Church: "it has pleased God to make men and women holy and to save them, not as individuals without any bond between them, but rather as a people who might acknowledge him in truth and serve him in holiness" (GE 6). According to Pope Francis, no one saves oneself as "an isolated individual, but God attracts us, taking into account the complex network of interpersonal relationships that develop in the human community: God wanted to enter into the dynamics of the people" "as an isolated individual. Rather, God draws us to himself, taking into account the complex fabric of interpersonal relationships present in a human community. God wanted to enter into the life and history of a people" (GE 6). It is not difficult to notice that this communal, ecclesial aspect of striving for holiness emphasized by Francis in his exhortation is clearly present in Wyszyński’s teachings. However, the Pope justifies the necessity and specificity of prayer without referring to its ecclesial dimension (cf. GE 147-157), which was so characteristic of Wyszyński.

\section{The Anthropological Dimension of Holiness}

A man or woman who strives for holiness is guided in their daily life by love and trust in Christ, and they realize their calling in a unique and unrepeatable way. Although in Wyszyński's ascetic teachings there are not too many statements about the anthropological dimension of holiness, the Primate indicated a great variety of paths leading to holiness quite vividly, at the same time pointing out that each baptized person is individually guided by God: "A nun sanctifies herself with her obedience. A priest sanctifies himself through his apostolic charity. Saint Paul indicated mothers' path to sanctification through bearing children. [...] Working for Christ is not just capering about in the meadow at will. Any work in God's kingdom must be acies bene ordinata. There are different temperaments, but each of us, apart from our own temperament and character, must also have Divine, Christlike temperament." ${ }^{43}$

43 Wyszyński, "Wy jesteście Ciałem Chrystusowym...”" No. 114*, 6. See: Hadryś, "Świętość w świetle ewangelicznych błogosławieństw," 11-25. 
He believed that saints are more to be admired than to follow, because God leads everyone differently towards Himself. ${ }^{44}$

Among the various forms of fulfilling the call to holiness and the apostolate, Cardinal Wyszyński drew attention to the special and exceptional role of a woman who, regardless of being in a family or monastic life, is called to at least spiritual motherhood: "The woman, therefore, should perform a double function of the Church, as Christ's Bride and mother of souls, which the Church faithfully expresses and fulfils." ${ }^{45}$ He repeatedly showed Blessed Virgin Mary to the members of the Institute as a model to follow: "The most important thing will always be [...] the calling to offer the sacrifice of your life together with Christ and following the example of Mary. [...] Just as Mary was called upon to take part in the act of world renewal through the service to the Lamb of God - as the Beautiful Sheep - each of you has to be like She was and serve Christ according to Her." ${ }^{36}$ However, according to the Primate, the following hierarchy should always be preserved: "First Christ, then Mary will come, and only then all the saints who are copies of Christ. Instead of looking at the copy, we are to reflect the spiritual image of Christ." ${ }^{37}$

There are many ways which lead to holiness. In this context, Pope Francis recalled the teaching of the Second Vatican Council: "Strengthened by so many and such great means of salvation, all the faithful, whatever their condition or state, are called by the Lord - each in his or her own way - to that perfect holiness by which the Father himself is perfect [...] Each in his or her own way" (GE 10-11). It is important to follow the example of the lives of Saints, but their lives cannot be fully copied, as this could take the baptized person away from the specific way prepared by God for them (cf. GE 11). For this reason, it is important that each believer recognizes their own way and "that they bring out the very best of themselves, the most personal gifts that God has placed in their hearts (cf. 1 Cor 12:7), not wasting strength trying to imitate something that was not for them. [...] There are many existential forms of testimony" "that they bring out the very best of themselves, the most personal gifts that God has placed in their hearts (cf. 1 Cor 12:7), rather than hopelessly trying to imitate something not meant for them. We are all called to be witnesses, but there are many actual ways of bearing witness" (GE 11). In the above context, it is also worth remembering that Pope Francis, being aware of the variety of ways to holiness, made it clear that "Not everything a saint says is completely faithful to the Gospel; not everything he or she does is authentic or perfect. What we need to contemplate is the totality of their life, their entire journey of growth in holiness, the reflection of Jesus Christ that emerges when we grasp their overall meaning

\footnotetext{
44 Cf. Wyszyński, "Homilia na uroczystość Wszystkich Świętych,” No. 1958, 3.

45 Wyszyński, "Kobieta w dziejach Kościoła," No. 480, 9. Cardinal Wyszyński invoked, among others, the figures of Saint Catherine of Siena and Saint Teresa of Lisieux.

Wyszyński, "Maria - Pulchre Agne...," No. 2676, 3.

47 Cf. Wyszyński, "Zapatrzeć się w Chrystusa," No. 110*, 12.
} 
as a person" "Not everything a saint says is completely faithful to the Gospel; not everything he or she does is authentic or perfect. What we need to contemplate is the totality of their life, their entire journey of growth in holiness, the reflection of Jesus Christ that emerges when we grasp their overall meaning as a person" (GE 22). Among various forms of fulfilling the call to holiness, Pope Francis emphasized the "feminine genius" which, as he noted, manifested itself in women's styles of holiness (cf. GE 12). The Holy Father remembered Saint Hildegard of Bingen, Saint Bridget, Saint Catherine of Siena, Saint Teresa of Avila and Saint Teresa of Lisieux by names. It is easy to notice that Wyszyński had a similar perception of Saints, in whom God acts in various ways and leads to individual salvation, and who should not be taken as a model in everything but only in what is the most important, i.e., the direction they follow and their personal submission to God. The Primate, just like the Pope today, emphasized and appreciated the role of women in the Church and the specific nature of their striving for the totality of life in God.

\section{Conclusion}

Due to the limited volume of this article, the research conducted on the fulfilment of the call to holiness in the approach held by the Servant of God Stefan Cardinal Wyszyński and its topicality in the light of Pope Francis' Gaudete et exsultate, is not fully covered, but is only an outline of the problem and encouragement for further research. In the author's opinion, despite its limitations it can be concluded that:

1. Wyszyński, justifying the universality of the call to holiness with the teachings of the Second Vatican Council and with the reception of the sacraments of baptism and confirmation, made additional reference to the call to the apostolate. He did it so many times, believing that in order to succeed in helping others attain salvation personal holiness is required.

2. The Primate was aware that each baptized person fulfils their own holiness, and a personal relationship with Christ is a key element in fulfilling the call to holiness and fruitful submission to Christ. He pointed to the connection between the moral dimension of holiness and its theological dimension, emphasizing the need to perceive Christ in relations with neighbours. He stressed the need to be sensitive to others and pay attention to the ones who have gone astray the furthest. Moreover, he pointed out the importance of small, everyday gestures of love. He initiated the Social Crusade of Love.

3. Wyszyński emphasized the ecclesial dimension of the pursuit of holiness, believing that the actions of a baptized person, even unconsciously, reflect the actions of the Church. In his view, baptized people come to Church not because of 
some legal ties, but due to spiritual or supernatural bonds. He indicated the variety of ways which lead to holiness, stressing that each baptized person is individually led by God. Among various forms of fulfilling the call to holiness and the apostolate, he drew attention to the unique role of women who are called to spiritual motherhood. He repeatedly pointed to Blessed Virgin Mary as a model to be followed.

4. Pope Francis and Cardinal Wyszyński have a very similar understanding of fulfilling the call to holiness, frequently using the same words and even similar expressions. It seems that this is primarily due to their statements being deeply rooted in the teachings and tradition of the Church, and of the Second Vatican Council in particular, as well as due to the nature of the teaching, which was not a theological lecture, but a pastoral message: both Wyszyński and Pope Francis wanted to touch human hearts and enlighten them with the desire to pursue holiness.

5. Wyszyński clearly highlights the universality of the call to holiness, the diversity of ways leading to it, as well as the link between the pursuit of personal holiness and the commitment to building the Kingdom of God. Pope Francis shares similar ideas, although it can be noted that Wyszyński placed particular emphasis on individual service to others, while Pope Francis emphasized actions of social and humanitarian character.

6. It is particularly significant that Wyszyński paid attention to the necessity of a deep and personal relationship with Christ. Christocentricity in fulfilling the call to holiness can be observed even in Wyszyński's teachings about Virgin Mary, as the focus on the person of the Saviour was quite often "inscribed" in the Marian dimension of spiritual life by the primate. ${ }^{48}$ It is noteworthy that in fulfilling the call to holiness, Pope Francis also emphasizes the necessity of a profound bond with Christ.

7. Wyszyński's teachings about the realization of the call to holiness has not lost its topicality despite the changing existential conditions of the baptized people's life. In many respects it is identical to the teachings of Pope Francis, yet in some of them accents are placed differently. However, it seems that it would not be an exaggeration to conclude that the Primate of the Millennium, through his teachings in the area of fulfilling the call to holiness, is to a large extent the precursor of Pope Francis' teachings in the exhortation Gaudete et exsultate. The teaching of both the Pope and the Cardinal is based on the Revelation and the Magisterium of the Church and is characterized by a positive and open attitude to people and world.

48 Marian aspects of fulfilling the call to holiness according to Wyszyński, included in his ascetic teachings, are the subject of a separate study, which the author of the following article intends to publish after the beatification of the Primate. 
The fulfilment of the call to holiness in the approach held by the Servant of God Stefan Cardinal Wyszyński, outlined in this article on the basis of his ascetic teaching addressed to the members of the Secular Institute of Helpers of Mary may be an incentive to conduct further research on the issues of holiness in the teachings of the Primate of the Millennium. The comparison of the public and well-known statements of the Primate on this subject, which, as already mentioned, have been elaborated on in various ways, with his teaching on this subject addressed to lay consecrated persons seems to be a particularly important topic. This comparative analysis could offer a more comprehensive insight into the primate's reflections concerning the fulfilment of the baptismal calling to holiness, as well as indicate where he placed emphasis when speaking to all the faithful and consecrated lay people. ${ }^{49}$ It may as also be interesting to analyse Wyszyński's statements concerning the sources and means of sanctification and the ways of using them which he recommended, as well as to determine to what extent they have remained valid in terms of theological and pastoral guidelines present in the Church during the period of preparation for the Primate's beatification. Certainly, it is worthwhile to comprehensively elaborate on the issue of the call to holiness in the approach of the Primate of the Millennium, taking into account all Wyszyński's source texts, i.e. official, public statements (sermons, homilies, pastoral letters) and his ascetic conferences and homilies addressed to Helpers of Mary, and also complete a comparative analysis with the teachings of Pope Francis contained not only in Gaudete et exsultate, but also in all his homilies and speeches.

Translated by Grzegorz Knyś

\section{Bibliography}

\section{A. Publications}

Bartoszewski, G., "Ku beatyfikacji," Ateneum Kapłańskie 3 (2001) 506-510.

Bortkiewicz, P., Etos pracy. Nauczanie moralne i społeczne Kardynała Stefana Wyszyńskiego (Studia i Materiały 43; Poznań: Wydawnictwo Wydziału Teologicznego UAM 2001).

Bortkiewicz, P., "Zbawczy charakter pracy człowieka w nauczaniu kardynała Stefana Wyszyńskiego," Vivere in Christo. Chrześcijański horyzont moralności (eds. J. Nagórny - A. Derdziuk) (Lublin: Redakcja Wydawnictw KUL 1996) 291-310.

Catechism of the Catholic Church (1992).

de Caussade, J.-P., Abandonment to Divine Providence (San Francisco, CA: Ignatius Press 2011).

49 For example, in the case of lay consecrated people, it is noteworthy that the Primate repeatedly draws arguments for caring about personal holiness from the apostolic nature of their calling - much more often than from receiving the sacrament of baptism. 


\section{JACEK HADRYŚ}

Dąbrowski, M., "Moralno-pastoralne aspekty świętości adhortacji apostolskiej «Gaudete et exsultate»," Homo Dei 87/1 (2019) 19-27.

Ewartowska, J., "Bóg Ojciec a przybrani synowie - teza o usynowieniu ludzkości w ujęciu Prymasa Stefana Wyszyńskiego," Communio 3 (2001) 41-57.

Francis, Gaudete et exsultate. On the Call to Holiness in Today's World (2018) (= GE)

Fortuniak, Z., "Chrześcijańska koncepcja pracy księdza Kardynała Stefana Wyszyńskiego," W kierunku człowieka (ed. B. Bejze) (Warszawa: Akademia Teologii Katolickiej 1971) 85-103.

Głowacki, P., “Wierność Bogu znakiem chrześcijańskiego życia. Refleksja nad duchowością Kardynała Stefana Wyszyńskiego w świetle Zapisków więziennych," Studia Włocławskie 4 (2001) 29-38.

Gogola, J., Teologia komunii z Bogiem. Synteza teologii duchowości (Kraków: Wydawnictwo Karmelitów Bosych 2012).

Hadryś, J., Dynamika chrześcijańskiego życia duchowego (Studia i Materiały 188; Poznań: Wydawnictwo Wydziału Teologicznego UAM 2017).

Hadryś, J., “Jedna świętość czy dwie różne? «Gaudete et exsultate» by Pope Francis and «non possumus» by Stefan Cardinal Wyszyński," Świętość - wysiłek czy łaska? Wokół adhortacji „Gaudete et exsultate” papieża Franciszka (eds. P. Roszak - P.P. Orłowski) (Scripta Theologica Thoruniensia 48; Toruń: Wydawnictwo Naukowe Uniwersytetu Mikołaja Kopernika 2019) 111-126.

Hadryś, J., "Różne ujęcia pełni życia chrześcijańskiego," Zawsze z Tobą. A Commemorative Book Offered to Bishop Zdzistaw Fortuniak on the 50th Anniversary of his Priesthood (ed. J. Hadryś) (Poznań: Wydawnictwo Wydziału Teologicznego UAM) 243-247.

Hadryś, J., "Świętość w świetle ewangelicznych błogosławieństw. Analiza trzeciej części Gaudete et exsultate papieża Franciszka," Drogi do świętości. Szkice nie tylko o świętych (ed. J. Hadryś) (Poznań: Wydawnictwo Wydziału Teologicznego UAM 2018) 11-25.

Król, L., "Rola pracy w formacji życia duchowego według kard. Stefana Wyszyńskiego," Studia Włocławskie 4 (2001) 39-52.

Maćko, W., "Znaczenie modlitwy dla posługi życia kapłańskiego w nauczaniu kard. Stefana Wyszyńskiego," Collectanea Theologica 76/3 (2006) 83-91.

Misiurek, J., "Chrześcijańskie życie duchowe w świetle nauczania kard. Stefana Wyszyńskiego (zm. 1981)," Historia i teologia polskiej duchowości katolickiej (Lublin: Redakcja Wydawnictw KUL 2001) III, 398-420.

Miziołek, W., “Życie i duchowość Stefana Wyszyńskiego Prymasa Polski," Życie wedle Ducha, (ed. E. Weron) (Poznań: Pallottinum 1987) 9-34.

Plans Belda, M., Guiados por el Espíritu de Dios. Curso de teología espiritual (Colección Pelícano; Madrid: Palabra 2006).

Second Vatican Council, Dogmatic Constitution on the Church "Lumen gentium" (1964) (=LG). Thomas à Kempis, The Imitation of Christ (trans. W.C. Creasy) (Notre Dame, IN: Christian Classics 1989).

Tomziński, J., “Prymas spod znaku Jasnej Pani,” Ateneum Kapłańskie 74 (1982) 77-91.

Urbański, S., "Chrystoformizacja - mistyczne naśladowanie Jezusa," Duchowość w Polsce 11 (2009) 233-243. 
Werbiński, I., “Duchowość pracy ludzkiej według kardynała Stefana Wyszyńskiego," Święty i Mąż Stanu. W hołdzie Stefanowi kardynałowi Wyszyńskiemu (ed. J. Hadryś) (Poznań: Wydawnictwo Wydziału Teologicznego UAM 2018) 105-131.

Wyszyński, S., "ABC Społecznej Krucjaty Miłości," http://www.duchprawdy.com/krucjatamilosci.htm [access: 24.10.2020].

Wyszyński, S., "Środki Bożego awansu człowieczeństwa i chrześcijańskiego humanizmu, Warszawa August 2, 1966," S. Wyszyński, Idzie nowych ludzi plemię (Poznań: Pallottinum 1973) 25-30.

\section{B. Typescripts ${ }^{50}$}

Wyszyński, S., "Modlitwa Zespołu," Dzień skupienia Instytutu Prymasowskiego, Laski 10.12.1957, No. 18.

Wyszyński, S., “Zapatrzeć się w Chrystusa,” Rekolekcje Ósemki, Laski 2.08.1952, No. 110*.

Wyszyński, S., "Wy jesteście Ciałem Chrystusowym..., Rekolekcje Ósemki, Laski 3.08.1952, No. $114^{*}$.

Wyszyński, S., “«romka chleba» - z Marcinowego życia. Stosunek i spojrzenie na każdego człowieka - «Per Christum Dominum nostrum»," Do Prymasowskiego Instytutu podczas dnia skupienia, Warszawa 11.11.1960, No. 155.

Wyszyński, S., “Bóg jest Miłością,” Rekolekcje Instytutu Prymasowskiego, Warszawa 11.09.1963, No. 281.

Wyszyński, S., "Nadprzyrodzona zależność od Kościoła," Rekolekcje Instytutu Prymasowskiego, Warszawa 6.08.1964, No. 328.

Wyszyński, S., "Rozdział V i VI - O Powszechnym powołaniu do świętości; O celach ostatecznych Kościoła pielgrzymującego," Rekolekcje Instytutu Prymasowskiego, Warszawa 19.08.1965, No. 374.

Wyszyński, S., “Uroczystość Świętej Rodziny,” Warszawa 9.01.1966, No. 387.

Wyszyński, S., "Komentarz Konstytucji pastoralnej, rozdział II - Wspólnota ludzka," Dzień skupienia Instytutu Prymasowskiego, Warszawa 5.12.1966, No. 419.

Wyszyński, S., "Homilia o świętym Janie Vianney," Rekolekcje Instytutu Prymasowskiego, Warszawa 8.08.1967, No. 466.

Wyszyński, S., "Kobieta w dziejach Kościoła," Rekolekcje Instytutu Prymasowskiego, Warszawa 10.08.1967, No. 480.

Wyszyński, S., “Codzienność Świętej Rodziny i każdej rodziny," Homilia w święto Świętej Rodziny, Warszawa 12.01.1969, No. 588.

Wyszyński, S., "Apostolstwo świeckich w Kościele," Rekolekcje Instytutu Prymasowskiego, Warszawa 19.08.1970, No. 758.

Wyszyński, S., “Tajemnica powołania..., Dzień skupienia Instytutu Prymasowskiego, Warszawa 24.02.1971, No. 813 .

Wyszyński, S., “Światła Boże na ludzkich drogach," Rekolekcje Instytutu Prymasowskiego, Choszczówka 8.09.1971, No. 936.

50 The typescripts from the archives of the Primate Wyszyński Institute in Warsaw are listed chronologically retaining proprietary numbering. 


\section{JACEK HADRYŚ}

Wyszyński, S., “Podczas Mszy świętej,” Dzień skupienia Instytutu Prymasowskiego, Warszawa 23.12.1973, No. 1323.

Wyszyński, S., "Homilia na uroczystość Wszystkich Świętych,” Warszawa 1.11.1961, No. 1958.

Wyszyński, S., "Społeczny charakter osoby ludzkiej jako fundament apostolstwa," Rekolekcje Instytutu Prymasowskiego, Choszczówka 17.08.1976, No. 1941.

Wyszyński, S., “Charakter naszego Instytutu," Rekolekcje Instytutu Prymasowskiego, Choszczówka 18.08.1976, No. 1948.

Wyszyński, S., “Charakter Instytutu Pomocnic Matki Kościoła," Rekolekcje Instytutu Prymasowskiego, Choszczówka 30.08.1979, No. 2572.

Wyszyński, S., "Prośba o pomoc w pracy nad sobą," Rekolekcje Instytutu Prymasowskiego, Choszczówka 30.08.1979, No. 2573.

Wyszyński, S., "Słowo przed Mszą świętą," Choszczówka 14.01.1980, No. 2636.

Wyszyński, S., "Maria - Pulchre Agne..., Homilia wielkanocna," Choszczówka 7.04.1980, No. 2676.

Wyszyński, S., "Na drodze do odnowy wielkanocnej”, Dzień skupienia Instytutu Prymasowskiego, Choszczówka 20.02.1980, No. 2661.

Wyszyński, S., "Powołanie do apostolstwa," Rekolekcje roczne Instytutu Prymasowskiego, Choszczówka 29.09.1980, No. 2737.

Wyszyński, S., "Modlitwa przed Najświętszym Sakramentem," Rekolekcje roczne Instytutu Prymasowskiego, Choszczówka 30.09.1980, No. 2743. 